\title{
Histopathology of Sugar Beet Flowers and Seed Balls Infected with Colletotrichum dematium $\mathrm{f}$. spinaciae
}

\author{
Yoshiaki Chikuo* and Toshiya Sugimoto*
}

\begin{abstract}
The infection process of sugar beet flowers and seed balls by Colletotrichum dematium f. spinaciae was studied using light microscope and scanning electron microscope. When infection occurred at early stage of flowering, germ tubes produced appressoria and subsequently infection pegs penetrated the cuticle $3 \sim 4$ days after inoculation. Mycelia spread both inter- and intracellularly. Infected cells eventually collapsed, and lesions became visible about 5 days after inoculation. Mycelia were found not only on the surface of blackened seed caps or pericarps, but also in the inner space of the pericarp. In severe infection, mycelia also found between the seed coats and cotyledons. When infection occurred at the late flowering stage, mycelia were frequently observed on the seed surface, but less frequently inside the seed balls. These hyphae were found in the periphery of the apical pore or inside the seed coat. The results indicate that this pathogen is seed-borne.
\end{abstract}

(Received December 6, 1988)

Key words: sugar beet, anthracnose, infection process, scanning electron microscopy.

\section{INTRODUCTION}

Since 1981 when an outbreak of anthracnose disease occurred in sugar beet fields in Japan, Colletotrichum dematium f. spinaciae (Ellis et Halst.) von Arx became a significant problem in seed production of sugar beet ${ }^{3}$. The pathogen also causes damping-off, petiole and leaf spot of sugar beet for root crop. Infestation of the seed production fields resulted not only in yield loss of seeds but also in deterioration of seed quality due to contamination.

A seed ball of sugar beet is a fruit consisting of three parts, i.e. seed cap, true seed and pericarp. True seed, which is the seed from the botanical point of view, is lying within dead corkey tissue (pericarp). Seed cap covers the upper part of the true seed (Fig. 1) ${ }^{1}$.

Although varietal differences in susceptibility to the pathogen ${ }^{5)}$, survival of the pathogen in soil ${ }^{4)}$ and chemical control measures ${ }^{2,10}$ ) have been described, establishment process of the pathogen in flower and seed balls has not been studied in detail.

The purpose of the present work was to observe conidial germination, penetration by infection peg, and establishment of $C$. dematium $\mathrm{f}$. spinaciae in the sugar beet flower and seed balls using light microscope (LM) and scanning electron microscope (SEM).

\section{MATERIALS AND METHODS}

Inoculation. Two lines of sugar beet, TK-76-49/2 mm-CMS and TK-76-49/2 mm-O, were used throughout the experiments. These lines are susceptible to anthracnose ${ }^{5}$. The

* Hokkaido National Agricultural Experiment Station, Hitsujigaoka-1, Toyohira-ku, Sapporo 004, Japan 北海道農業試験場 
sugar beet, as a biennial crop, requires usually two years for seed production. Mother beet plants or stecklings were grown from seeds during the first year. Stecklings were planted in pots, placed in a greenhouse and allowed to bolt for seed production after an overwinter storage. Just before flowering, inflorescence was bagged for each line separately to prevent spontaneous cross pollination. Pollination was done by exchanging bags covering inflorescences.

Inoculation was made by spraying conidial suspension of $C$. dematium $\mathrm{f}$. spinaciae (Isolate, CS-22M) on inflorescence of the CMS line 7 (stage 1) or 21 days (stage 2) after pollination. Stages 1 and 2 correspond to periods of cotyledon differentiation and maturation of seed organs, respectively $^{9}$. Flowers or seed balls were harvested 2, 3, 4, 5, 7, 11 and 14 days after inoculation.

Tissue preparation for $\boldsymbol{L M}$. Samples were fixed in FAA for $24 \mathrm{hr}$, dehydrated through an ethanol series and embedded in paraffin. They were cut and stained with $0.1 \%$ cotton blue in lactophenol.

Tissue preparation for SEM. Samples were fixed in $5 \%$ glutaraldehyde in $0.1 \mathrm{M}$ phosphate buffer ( $\mathrm{pH} 7.4$ ) for $1.5 \mathrm{hr}$ at room temperature, post-fixed in $2 \%$ osmium tetroxide in the same buffer for $12 \mathrm{hr}$ at room temperature, dehydrated in an ethanol series for $30 \mathrm{~min}$ per step and dried in a critical-point dryer. They were mounted on aluminum stubs and coated with gold using an ion coater. Observations were made at $10 \mathrm{kV}$ under JSM-T200 SEM.

\section{RESULTS}

\section{Infection process of sugar beet anthracnose}

Observations were focused on infection process on the seed cap since, in most cases, symptoms developed first on the seed cap and then spread over the whole seed.

\section{Stage 1 (Infection at the early stage of flowering)}

Conidia germinated and produced appressoria on the cuticle of the seed cap two days after inoculation (Plate I-1). Upon germination, a septum appeared in the center of the conidia, and germ tubes grew out from one or both cells of the conidium. The appressoria tended to develop on the sutures between epidermal cells (Plate I-1, 2).

Infection pegs emerging from the appressoria were observed $3 \sim 4$ days after inoculation. The infection peg was thin, and hyphae developed gradually to their normal size within the host cells (Plate I-3). Penetration through stomatal openings was rare.

The fungus spread both inter- and intracellularly through the seed cap (Plate I-4, 5, 9). Infected cells eventually collapsed, and lesions became visible about 5 days after inoculation (Plate I-4, 6). Five to seven days after inoculation, sporulation was observed on the seed caps, anthers and perianthes.

In cross sections of the flowers, 11 14 days after inoculation, seed caps including apical pore were filled with hyphae (Plate I-5, II-3), which reached the fruit cavity and covered all over the inner surface of the pericarp. The hyphae also invaded the developing true seed causing tissue collapse. True seeds died before maturation consequently (Plate I-7, 8, II-1).

\section{Stage 2 (Infection at the late stage of flowering)}

Whereas seed balls have developed almost completely at this stage, true seeds often remained immature leaving cavity within seed balls.

Mycelia were frequently observed on the surface of the seed balls (Plate II-4) and less frequently within seeds, although these seeds could mature. A few mycelia existed in the periphery of the apical pore (Plate II-5, 6) and under the seed coat (Plate II-7, 8). The invasion of the pathogen from the basal pore or peripheral zone was not observed.

\section{DISCUSSION}

Sugar beet flowers and seed balls were susceptible to infection by $C$. dematium $\mathrm{f}$. spinaciae at all the developmental stages. However, there was a close relationship between disease severity 


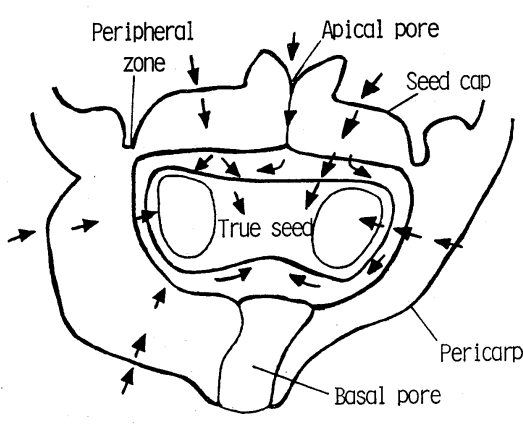

STAGE 1

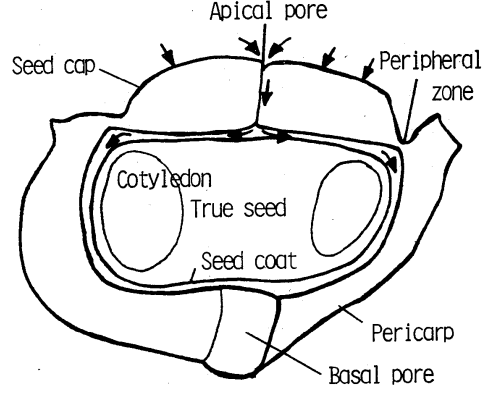

STAGE 2

Fig. 1. Diagram of a transverse section of sugar beet seed ball. Arrows indicate the possible routes of invation of Colletotrichum dematium $\mathrm{f}$. spinaciae.

and infection stage. The pathogen easily penetrated seed caps through cuticle at the early stage of flower development (7 days after pollination, stage 1), resulting in either plant death or seed contamination. This mode of infection was in accordance with other anthracnose ${ }^{11,13)}$. Invasion through stomata does not seem to be common. At the late stage of flower development (21 days after pollination, stage 2), however, the pathogen could hardly penetrate the tissues and remained only on the surface. Present observations were summarized in Fig. 1. These findings together with previous one ${ }^{3}$ ) indicate that the pathogen was seed-borne.

The tissues surrounding the true seed become impervious with time ${ }^{8)}$ and could form a barrier to fungal invasion. Openings which allow the air and water to enter on germination can be entrances for the pathogens, e.g. basal pore in the pericarp ${ }^{12)}$, peripheral zone forming the slit between the seed cap and pericarp $\left.{ }^{6}\right)$ and apical pore in the seed cap ${ }^{7)}$. El-Nashaar and Bugbee ${ }^{7}$ actually confirmed that Phoma betae invades seeds via these three openings. In the case of anthracnose, however, profuse hyphae covering the apical pore inside the seed cap at both stages (Plate II-3, 5 and 6), together with observations that symptoms first develop on the seed cap, indicate that the apical pore serves as the entrance for the pathogen.

We wish to thank Mr. R. Satoh, Hokkaido Nat. Agric. Exp. Stn., for technical assistance of SEM. We also thank Dr. B. Sneh, Tel-Aviv University, Israel, and Dr. N. Matsumoto, Hokkaido Nat. Agric. Exp. Stn. for their helpful advice in the preparation of the manuscript.

\section{Literture cited}

1. Artshwager, E. (1927). J. Agric. Res. 34: 1-25.

2. Chikuo, Y., Endo, T. and Sugimoto, T. (1983). Proc. Sugar Beet Res. Assoc. Japan 25: 41-46.

3. Chikuo, Y. and Sugimoto, T. (1984). Ann. Phytopath. Soc. Japan 50: 249-254.

4. Chikuo, Y. and Sugimoto, T. (1984). Proc. Sugar Beet Res. Assoc. Japan 26: 141-145.

5. Chikuo, Y., Sugimoto, T. and Endo, T. (1984). Ann. Phytopath. Soc. Japan 50: 46-52.

6. Coumans, M. (1978). Biologia Plantarum 20: 114-118.

7. El-Nashaar, H. and Bugbee, W.M. (1981). J. Am. Soc. Sugar Beet Technol. 21: 11-22.

8. Heydecker, W., Chetram, R.S. and Heydecker, J.C. (1971). Ann. Bot. 35: 31-42.

9. Hosokawa, S. (1980). Tensai (The sugar beet). Yokendo, Tokyo.

10. Kawakatsu, M., Mizoguchi, T., Tanabe, H., Sugimoto, T. and Chikuo, Y. (1984). Proc. Sugar Beet Res. Assoc. Japan 26: 146-150.

11. Manandhar, J.B., Kunwar, I.K., Singh, T., Hartman, G.L. and Sinclair, J.B. (1985). Phytopathology 75: 704-708.

12. Perry, D.A. and Harrison, J.G. (1974). Ann. appl. Biol. 77: 51-60.

13. Roberts, R.G. and Snow, J.P. (1984). Phytopathology 74: 390-397. 


\section{和 文 摘 要}

\section{築尾嘉章・杉本利哉：テンサイ花器（球果）に対する炭そ病菌の感染過程}

テンサイ花器に対する炭そ病菌の感染過程を光学拈よび走査型電子顕微鏡で観察した。宿主への侵入はク チクラ貫入により接種後 3〜4 日目に起こった。菌杀は細胞間および細胞内を伸長し, 接種後 5 日目には病 斑が形成された。開花初期に本菌に感染すると菌系は未熟な蒴蓋などから容易に侵入でき, 細胞内に充満し た。激発すると菌糸はさらに生育を続け蒴蓋と果皮にとり囲まれた真正種子の内部にまで到達し, 結実を妨 げた。開花後期に感染した場合は，菌杀は球果表面に多くみられたが，内部ではほとんど観察されず球果は 結実した。しかし蒴蓋自然開口部周辺や真正種子の種皮下に少数の菌糸が観察され, 本菌は感染時期をとわ ず球果内部に侵入していることが確認された。以上の結果から，テンサイ炭そ病菌は種子伝染性であると判 定された。

\section{Explanation of plates}

Plate I, 1 8 and Plate II, 1 3: Scanning electron micrograph and light micrograph of sugar beet flowers (seed balls) infected with Colletotrichum dematium f. spinaciae 7 days after pollination (stage 1).

Plate II, 4 8: $\quad$ Infected 21 days after pollination (stage 2).

\section{Plate I.}

1. Germinated conidia of $C$. dematium f. spinaciae having a septum in the middle of the spores and appressorium at the tip of the germ tube on the seed cap. Three days after inoculation (scale: $10 \mu \mathrm{m})$.

2. Close up of an appressorium (scale: $10 \mu \mathrm{m}$ ).

3. Appressorium on penetration hypha, 4 days after inoculation:

4. Cross section of seed cap, 5 days after inoculation.

5. Cross section of seed cap, 11 days after inoculation.

6. Leaf surface with a lesion, 5 days after inoculation. Note the penetration hypha and an appressorium.

7. Cross section of heavily infected flower with mycelium covering embryo, 14 days after inoculation (scale: $1,000 \mu \mathrm{m}$ ).

8. Cross section of heavily infected flower having penetration hyphae within the true seed, 14 days after inoculation.

9. Pericarp tissue with intracellular hyphae. Note hyphae passing from cell to cell.

Plate II.

1. Close up of immature seed ball. Acervuli were formed inside the seed coat, 14 days after inoculation (scale: $1,000 \mu \mathrm{m}$ ).

2. Inner view of healthy seed cap with an apical pore (scale: $100 \mu \mathrm{m}$ ).

3. Inner view of infected seed cap with hyphae covering the entire inner surface, 14 days after inoculation (scale: $100 \mu \mathrm{m}$ ).

4. Outer view of seed cap with a stigma (star-shaped). Note the hyphae creeping on the stigma (scale: $1,000 \mu \mathrm{m}$ ).

5. Cross section of the seed ball, true seed developing within the fruit cavity between the pericarp and seed cap. Note the apical pore (arrow) of the seed cap (scale: 1,000 $\mu \mathrm{m}$ ).

6. Close up of the apical pore of Plate II-5. Note hyphae (scale: $10 \mu \mathrm{m}$ ).

7. Cross section of the seed ball. Note seed organs completely differentiated (scale: $1,000 \mu \mathrm{m}$ ).

8. Close up of Plate II-7. Penetration hyphae (arrow) can be seen beneath the seed coat (scale: 100 $\mu \mathrm{m})$.

Abbreviations used in plates: A: appressorium, $\mathrm{C}$ : conidium, CO: cotyledon, $\mathrm{H}$ : hyphae, SC: seed cap, TS: true seed, P: pericarp. 
Plate I
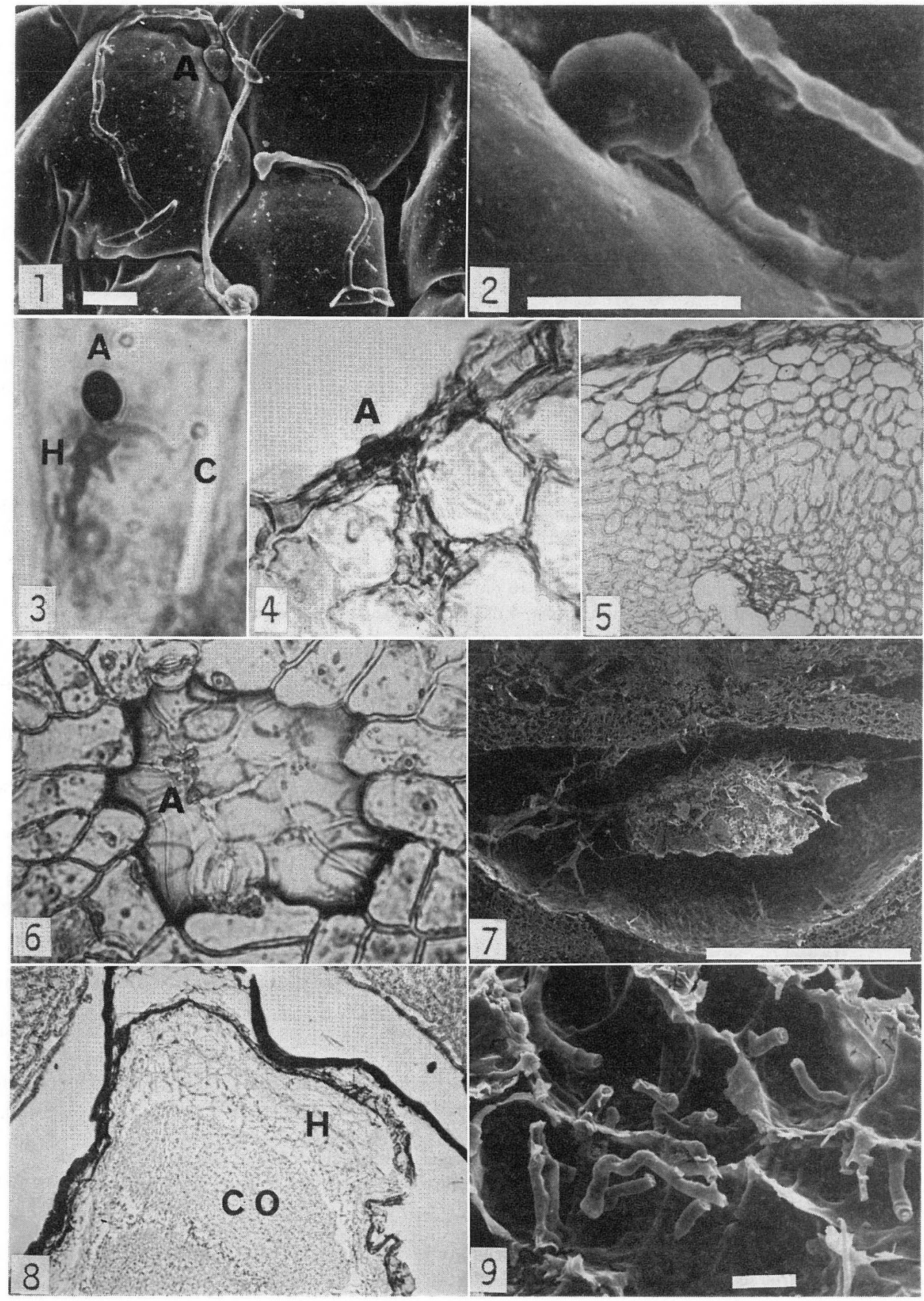


\section{Plate II}

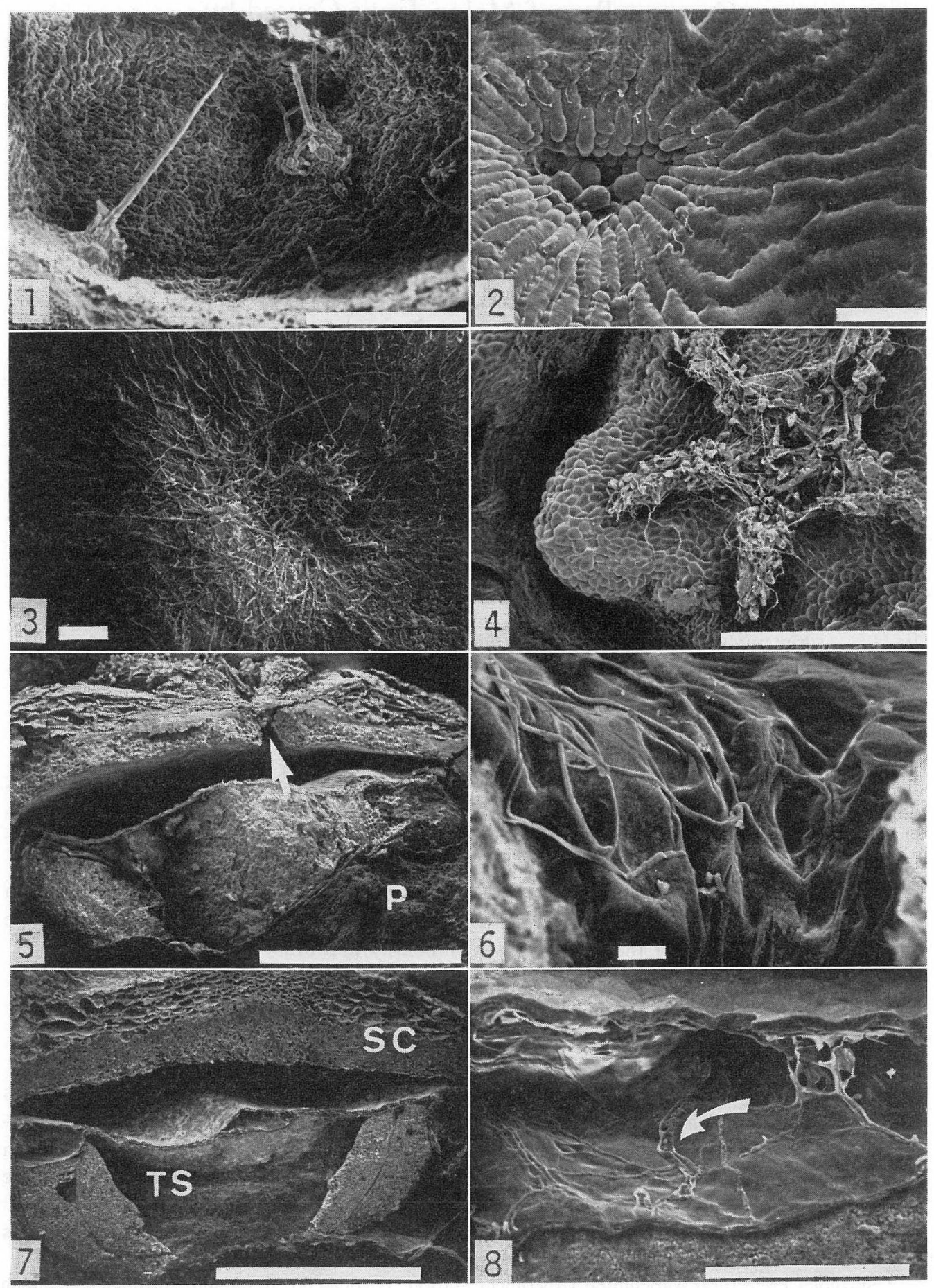

